\title{
The Balance Between Corporate Identity And Corporate Image And Its Impact On Marketing Of Universities In Ghana
}

\author{
Nana Danso Boafo \\ Fred Agyapong \\ Priscilla Asare \\ Grace Amponsah
}

\begin{abstract}
Universities are adopting different strategies to attract students, enhance satisfaction level and loyalty as well as branding in a competitive market. Although university corporate identity and image is becoming an increasingly important issue in the marketing of universities in Ghana, there is sometimes a mismatch between the university corporate identity and image which can lead to poor marketing performance. This has therefore necessitated this study which is, evaluating the balance between corporate identity and corporate image and its impact on marketing performance of universities in Ghana using Christian Service University College as the case study. The study was descriptive. Population was past and current students of the university. Five hundred and seventy five (575) persons were sampled using convenience sampling method. Multiple linear regression was used to analyze data. Findings revealed a balance between CSUC corporate identity and corporate image, as it has positively impacted on the university's marketing performance in these challenging times for private universities in Ghana. This was based on the evidence that, majority of the responses attested to the fact that the university practiced its Christian values inbuilt in its brand , also the university does what it says it stands for. Respondents were happy with lecturers and the university graduates' performances on the field. The study recommended that Universities must create a perfect fit between their corporate identity and corporate image since they impact on their marketing performance, and also all staff must be made to understand the relationship between the institution's corporate identity and corporate image and its impact on marketing performance of the institution.
\end{abstract}

Key words: university, corporate identity, corporate image and marketing performance. 


\section{INTRODUCTION}

Every organization needs a clear image and this is something that can be influenced from the inside. Different experiences, beliefs, attitudes, information, feelings and observations, all go into the process of forming an image (Pitkänen 2001). Image is how stakeholders perceive a company or its products/services. A company creates an identity in the hopes of molding their public's impression of them. Of course, other factors influence the image as well and so it may not always coincide with the identity (Management Study Guide, 2015).

Corporate identity is the influencing factor. It is how a company aims to be recognized or identified and should match the expectations of both customers and employees about what the organization stands for, where it is heading and what its strengths, weaknesses and principles are. It should have a clear personality Balmer, (2007), Birkigt and Stadler's (2006) theory of symbolism, communication and behavior explains how to obtain a beneficial corporate identity that develops from the company itself (Otubanjo 2013). It could be said that a corporation's identity shapes the image a company wants to create for itself and even unintentionally builds the image the stakeholder has. Corporate identity is the determining factor behind what the company is seen as and how the company wants itself to be seen. Corporate image becomes part of the corporate identity as it is shaped by the choices made by the company. Everything the company does is basically built inside corporate identity, which becomes the corporate image, which takes into account all the factors stakeholders see of the company's processes, products and services (European Institute for Brand Management, 2009).

Almost all universities have a unique image and this image is formed on the basis of perception of its stakeholders, whether the organization does good jobs for them or not. A university's corporate image is an overall perception of the institution held by different segments of the public (Villanova, Zinkhan and Hyman, 2002). Through this definition, there are two main key phrases that are keenly understandable. The first is "Overall perception" and second one is "Different segments". Overall perception is developed through what the university is likely to do for its stakeholders in terms of benefits, what the benefits the stakeholders seek in the view of stockholder, board director, employee, supplier, channel members, customer and community. That contributes to overall perception of these stakeholders. Second is the how the university deals with the different segments of the public (Carroll 2013).

Over the past two decades, the operating landscape of universities in Ghana has witnessed noticeable changes due to macro- and micro-environmental forces. These changes range from technological advancement and a saturated domestic market, increasingly demanding and sophisticated consumers (students), as well as escalating competition. With these changes, there is need for universities in Ghana to revamp their existing marketing strategies (Watchravesringkan et al., 2010). The corporate image and identity of a company is very important like products or services offered.

Indeed, according to Kotler (2001), organizational success is a direct consequence of corporate image and identity which is measured as a significant feature of current marketing strategy. Competition among the universities is highly increasing. Consequently, universities are adopting different strategies to attract students, enhance satisfaction level, loyalty as well as branding in the competitive market. For Ghanaian universities, the strength and marketing power of an 
Baofo, N. D., Agyapong, F., Asare, P., \& Amponsah, G. (2020) The Balance Between Corporate Identity And Corporate Image And Its Impact On Marketing Of Universities In Ghana. Archives of Business Research, 8(5). 302-315.

institution's brand is rapidly becoming one of the critical levers for differentiation and success. Although the balance between the university corporate identity and image is becoming an increasingly important issue in the educational sector in Ghana, not many studies have been done on its impact on marketing performance. This has therefore necessitated this study which is, to evaluate balance between corporate identity and corporate image and its impact on marketing performance of universities in Ghana using Christian Service University College as the case study.

\section{Corporate Identity}

\section{LITERATURE REVIEW}

Kapferer first mentioned the concept of corporate identity in 1986 and since then there have been many discussions of its definition (Janonis et al., 2007). According to Janonis et al. (2007), corporate identity includes everything that makes the company meaningful and unique. De Chernatony and Harris (2001) suggest that corporate identity includes values, aim and moral image that together constitute the essence of individuality that differentiate the brand. Corporate identity offers a possibility to position a brand and encourages strategic approach while managing it (De Chernatony and Harris, 2001). Kapferer (2008) suggests that corporate identity involves many dimensions and any communication from the brand; whether it is formal or informal, verbal or non-verbal, should be in sync with its corporate identity. According to Sääksjärvi and Samiee (2011), corporate identity represents how companies aspire to be perceived. They also suggest that the purpose of corporate identity is to establish a relationship between the brand and the customer (Sääksjärvi and Samiee, 2011).

\section{Types of Corporate Identity}

There are three kinds of corporate identity. These are Monolithic, Endorsed and Branded identity.

\section{Monolithic Identity}

This means that the whole company uses one visual style and the consistency between the corporate identity and the product identity is very strong, reflecting the corporation directly.

\section{Endorsed Identity}

This implies when the companies have their own style, but the parent company remains recognizable in the background. In this case, the link between the corporation and its different brands may take the shape of a common factor, tying the different brands together.

\section{Branded Identity}

The corporate identity can be branded where the subsidiaries have their own style and the parent company is not recognizable - the product represents the brand identities rather than corporate identity (Sääksjärvi and Samiee, 2011).

\section{Components of Corporate Identity}

According to De Chernatony (2009), corporate identity consists of four aspects; Personality, Positioning, Vision and Culture and Relationship. All aspects influence each other, however the company's vision and culture is the core aspect which determine and drive the brand's desired positioning, personality and the subsequent relationships. The corporate identity is passed on to stakeholders that reflect and interpret the identity as a presentation (De Chernatony, 2009). 


\section{Personality}

The corporate personality establishes what specific characteristics the company has, and these characteristics should indicate how the company would be in human life. By humanizing a company, it plays a more central part in consumers' lives which is good considering individuals are keener towards companies that share the same or similar ideas (Ponnam, 2007). Aaker (2007) also states that corporate personality refers to the set of human characteristics associated with a company. It regards how the corporate personality enables a consumer to express his or her self through the consumption of a brand. Furthermore, corporate personality increases consumer preference and usage, evokes emotions in consumers, and increases levels of trust and loyalty (Aaker, 2007).

\section{Positioning}

According to Kapferer (2008), companies can distinguish brands according to their positioning, which is when one emphasizes the distinctive characteristics that make it attractive to consumers and different from its competitors. Keller et al. (2002) agree that positioning sets the company apart from the competition. However, the researchers stress that companies also need to pay attention to other aspects of the positioning; understanding the frame of reference that your company is working in and address the features that your company has in common with the competition. This will ensure that the company has a better understanding of the market (Keller et al., 2002).

Kapferer (2008) further states that positioning controls the words that are communicated to the customer and can be explained as the brand's message and outward expression of the inner substance. However, the researcher rather refers to this as "phvsique", which mainly describes the companies' physical qualities and the company's performance characteristics (Kapferer 2008). Bronnenberg and Wathieu (2006) state that positioning is an important aspect that managers need to take into account when evaluating the promotion asymmetry and communication. Moreover, Sujan and Bettman (2009) believe that the aspects of the company itself, such as physical attributes or situational factors, determine which positioning strategy is best suited for the company.

\section{Vision and Culture}

As De Chernatony (2009) mentions, a company needs a clear vision that describes a well-defined direction of what it wants to achieve. Managers need to envisage the companies' environment for at least five years ahead and consider how the company is going to make the future world they operate in better (Collins and Poras, 2006). The company culture describes the set of values that are feeding the company's inspiration, as well as explains from where the product is derived (Kapferer, 2008). To improve the communication with consumers and decrease misunderstandings, Kapferer (2008) stresses that a company needs its own culture from which every product should originate. Banerjee (2008) adds that the cultural values are principles that determine how people perceive themselves and others. It is also highlighted that marketers need to view the corporate culture as a main weapon considering it can increase the competitive advantage in operating markets (Banerjee, 2008).

Kapferer (2008) and Schmidt et al. (2005) stress that culture links the brand to the firm and highlights the differencing factors, making it stand out from the competition Kapferer (2008) further states that these differentiating factors of the culture can refer to the basic principles 
Baofo, N. D., Agyapong, F., Asare, P., \& Amponsah, G. (2020) The Balance Between Corporate Identity And Corporate Image And Its Impact On Marketing Of Universities In Ghana. Archives of Business Research, 8(5). 302-315.

leading the company's outward signs, such as product and communication. It also mentions that countries of origin are for example a highly valuable factor used by well-established companies (Kapferer 2008). De Chernatony (2009) further elaborates that one needs to audit company culture in order to develop a strategy for reaching consumers. Schein (2004) believes that this can be measured through the company's visible artefacts, employees' and managers' values and mental models of the people involved in brand building activities. One can then understand which values have remained unchanged over time, such as core values, and values that have changed.

\section{Relationship}

Relationship is defined by Blackston (2002) as the interaction between consumers' attitude towards the company and the company's attitude towards the consumers. This means that consumers' perception plays an important part in the brand communication (Blackston, 2002). Kapferer (2008) stresses that companies should include the relationship facet into their brand in order to succeed in the process of transaction and exchange. Meenaghan (2005) adds that companies need to involve brands into the world of the consumer in order to gain a "magnetic" relationship between them. Kapferer (2008) and Lannon and Cooper (2003) agree that companies need to be the voice that the consumers hear. The communication should answer who you are, where you are in life and where you are going. Brands and consumers are therefore connected since they are part of ourselves and we are part of our brands (Lannon and Cooper, 2003). Swaminathan et al. (2007) and Fournier (2008) mention that consumers therefore form strong relationships with those brands that have values and personality associations that are similar to their self-concept.

Companies need to act, deliver and relate in accordance to the consumers, and also to consider this when communicating to the consumers. Every part of the communication, such as images and symbols must relate to and exploit consumers' values and lifestyles (Kapferer 2008). Broadbent and Cooper (2007) mention that can particularly be a way to increase the added value and differentiating factors of the company. Moreover, De Chernatony (2009) explains that the relationship and increased interaction can boost the innovation and success for the company, considering the company gain furthered understanding of the consumer.

\section{Corporate Image}

Corporate image is on the receiver's side in the Sender-Receiver model (Kapferer, 2008). It is the sum of impressions that affects how consumers perceive a company and identify or differentiate the company from others. Corporate image can also be defined as consumer's perceptions of a company as reflected by the brand associations held in consumers' memory (Keller, 2003). Aaker (2001) adds that the connection to a brand in the mind of the consumers will be stronger with associations. These associations can be further divided into subgroups, such as attitudes and benefits (Keller, 2003).

Attitudes have a direct impact on corporate image and are widely defined in research, making the concept abstract to reach a total understanding of (Faircloth et al., 2001). Nevertheless, brand attitudes are most frequently said to be consumers' overall evaluation of a brand and seen as a silent perspective of benefits and attributes (Keller, 1993). Benefits are the values consumers connect with the product or service and more specific what types of needs the product or service fulfil for the customer. Product or service benefits could for example be of functional, experiential 
or symbolic benefits (Keller, 2003). Individuals perceive the corporate image differently since they individually interpret the message based on their life experiences and specific characteristics as human beings (Dobni and Zinkhan, 2000).

Establishing a positive corporate image requires the establishment of a strong, favourable and unique association to the brand. When corporate images are strong, they can be used to enhance a person's self-image, appeal stakeholder and influence customers' purchase decisions, which in order has an impact on the corporation's financial revenue (Munoz, 2004). Interaction with a brand can also affect consumers' overall attitudes to the brand where for example individuals can feel a sense of belonging by consuming or buying a certain product. For instance, even if a customer does not belong to the elite class, they can feel a sense of belonging just by wearing a suit from Armani (Graeff, 2006). Products and brands can therefore be perceived to have symbolic meaning, which is part of the environment symbolized by the individual (Kapferer, 2008).

According to Hsieh, Pan, and Setiono (2006), a successful corporate image enables consumers to identify the needs that the brand satisfies and to differentiate the brand from its competitors, and consequently increases the likelihood that consumers will purchase the brand. Thus, a company or its product/ services which constantly holds a favorable image by the public, would definitely gain a better position in the market, sustainable competitive advantage, and increase market share or performance. In addition, Koo, (2003) points out that a favorable corporate image will lead to loyalty, brand equity, purchase behavior and brand performance. On his part, Reynolds (2005) noted that an image is the mental construct developed by the consumer on the basis of a few selected impressions among the flood of the total impressions; it comes into being through a creative process in which these selected impressions are elaborated, embellished, and ordered.

In an organization, image can generate value in terms of helping a customer to process information, differentiate the company, generating reasons to buy, give positive feelings, and providing a basis for extensions. Investing in branding is considered to offer such a company major competitive advantage. Brand names or brand equity are often considered to be important resources which the firm possesses. Therefore, creating and maintaining image of the company is an important part of a firm's marketing program and branding strategy (Keller, 2003). Consequently, it is important to understand the development of image formation and its consequences such as satisfaction and loyalty.

Research indicates that customers brand loyalty brings with it benefits such as greater sales, increased profitability, a customer base that is less sensitive to the marketing efforts of competitors, and substantial barriers to entry. Loyalty is often understood as consisting of both a behavioral and an attitudinal dimension (Dick and Basu, 2014), and thus refers to a deeply held dispositional commitment, which induces users to resist situational influences and marketing efforts that might have the potential to cause brands witching behaviors. Corporate image is a composite of perceived quality and esteemed dimensions that a customer holds and therefore reflecting a customer's overall impression. A positive corporate image can be considered as a crucial ability of a corporation to hold its market position (Wetzels et al., 2009).

\section{Characteristics of a Good Corporate Image}

There are several key characteristics that show corporate image to be favourable. 


\section{Consistency}

Corporate image must be consistent with the company' service portioning statements. Once the company defines who it is, what it offers and what benefit it provides to its target audience, it is important that this is reflected in its corporate image. Believable and Credible Corporate image must be believable in the minds of the public. It should not be image just written on papers but shown to the public. For example, if a company is trying to create an image of environmental concern, it would be ludicrous and unbelievable if its services destroys the environment through pollution or exploitation.

\section{Advertising Parallels}

Advertising strategies must parallel the image a company is striving to create. Advertising strategy of the company should be aligned to suite the corporate image of the company.

\section{Alignment with Similar Value}

"We are judged by the company we keep" is especially true in creating a corporate image. The people partnership and other businesses a company deals with will either help to reinforce its image or destroy it. It is important it partners or aligns itself with other organizations and people who share same or similar corporate values. Corporate image is the way the company is identified and perceived by the market. It is essentially the personality of an organization and what differentiates it from competitors. A good corporate image is created by its leadership team, its employees, marketing experts, public relations and media and other formalized form of promotion. But it is also defined by how well the company aligns its product services, and actions with the image it is trying to create. A good corporate image is what generates and promotes sales and revenue for a company and it is a reflection of day to day activities of the organization.

\section{Factors Affecting Corporate Image}

Corporate image has two main elements: the functional and the emotional. The functional component is related to easily measured concrete characteristics, while the emotional component is connected with feelings and attitudes towards a firm that come from individual experiences. Corporate image is, therefore, the result of a process by which the public compares and contrasts the various attributes of companies. The interaction of these factors results in distinguishing one company from all others (Weiwei 2007). All of the factors that go into forming an image about something are part of the experience. A company's logo is like the heart of the company; it is what reflects the company's identity and can be changed slightly to keep up with trends. Customers rarely hear a company's mission statement, codes of ethics, annual report or company slogan directly; they hear it through advertising or public relations. Then there is interacting with the company through its employees. They project the image of the organization, which is crucial in service organizations where personnel interactions can be the key to customer satisfaction. (Change Conversations 2013).

\section{Word of Mouth (WOM)}

Feedback is also extremely essential in the management of corporate identity. Without truthful information of the observations and opinions of customers as well as other stakeholders, a company cannot develop their image. A continuous stream of feedback through employees who are in constant contact with various stakeholders would be ideal because it could allow alterations to be made to a company's way of doing things without having to hire someone to conduct a formal 
study. It is reactive and fast. (Balmer, 2003.) It is more common to see word of mouth (WOM) linked to reputation than it is to see it linked to image. WOM can be seen as both the cause and the effect of corporate reputation.

Good WOM creates a positive image in the minds of stakeholders, which creates a good reputation. However, a successfully planned and communicated identity leads to a good image in the minds of stakeholders, which then leads to a reputation that generates WOM. (Williams, Buttle, and Biggemann 2012). It is important to generate positive WOM internally in order to reduce negative WOM and employee agitation externally. Social media is an extremely quick way to spread information and can often turn negative and potentially damaging to a company's reputation. (Pownall 2011.) This is why it is important to keep track of what is being said on the social media and to try and influence it in a positive way.

\section{Employer Image}

Like company image, employer image is how people perceive the company, but in this case the people are current and potential employees. It is about how they see the company and what they think it would be like to work there. Therefore, employer image is about a company effectively communicating its values, personality and culture in order to create a desired identity to its customers. It affects every aspect the company shares with employees; recruitment, socialization, training and development of career paths and even the process of leaving the company. Both the employer and company image need to be closely linked in order to present the company consistently and effectively. If how the company presents itself to the outside world and how its employees view the company are not in sync, the identity will have a confusing message and will fail to engage both external and internal stakeholders. The best employer images are realistic but always positive and create a picture people can relate to. To successfully shape an employer image one needs to invest in existing employees (Real Staffing, 2015).

\section{Defining Marketing}

Often there are misconceptions of the meaning of marketing. Foskett $(1998,49)$ highlights a considerable amount of confusion about this; Ivey and Naude $(2004,402)$ believe that confusion is more particular in the area of education. Misconceptions include the way this is usually approached as 'the promotional activities done by an institution in order to attract potential students and increase enrolment'. The confused understanding of marketing could be due to the fact that educators are unclear about the concepts of business. However, Wright $(1999,2)$ highlights that this case of limited and confused understanding of marketing is common among many senior managers in all areas of businesses, a case that is evident not only in educational institutions. Confusion surrounding the concept of marketing suggests that it needs further elaboration and clarification. Kotler and Armstrong $(2008,5)$ define marketing as a social and managerial process by which individuals and groups obtain what they need and want through the creation and exchange of products/services of value with others.

This definition embeds three main issues: (1) social process; the individual has needs to be satisfied, (2) managerial process in which the institution attempts to satisfy groups of individuals. This happens through (3) values exchange, simply purchasing the product/service. The American Marketing Association (AMA) defines it more comprehensibly as being the process of planning and 
Baofo, N. D., Agyapong, F., Asare, P., \& Amponsah, G. (2020) The Balance Between Corporate Identity And Corporate Image And Its Impact On Marketing Of Universities In Ghana. Archives of Business Research, 8(5). 302-315.

executing the conception, pricing, promotion and distribution of ideas, goods and services to create exchange and satisfy individual and organisational objectives (Brassington, 2006, 7).

Putting the definition more functionally in the educational sector, marketing is the means by which institution senior managers use sustained and thorough knowledge of present and future markets to ensure that strategic planning addresses the education and training needs of the customer, (student) cost-effectively (Further Education Funding Council., 1998). It is a management process that requires planning and analysis, resource allocation, control and investment. Together, these marketing activities provide what the customer wants (Brassington, 2006). Foskett $(1999,34)$ takes the concept of marketing further, by setting it as an overall philosophy for an organisation which encompasses and directs the entire business.

In this prospect, marketing clarifies institutional goals, unifies strategies, and utilizes resource efficiently. All these areas are aimed at having a more satisfied customer with the educational service that is offered (Wonder \& Gyure, 1991, 2).

On these understanding of what constitute marketing, we can say that the corperate identity and image plays a critical role on marketing performance. This means that marketing success is largely based on the totality performance of internal structures within a firm.

While some people might believe that students are the sole customers of the educational service, others believe it is not only students but also parents, prospective employers, and society as a whole, as they all benefit from the service (Ivy \& Naude, 2004).

\section{Theoretical Review}

The study based its theoretical foundation on the brand relationships theory

\section{Brand relationships Theory}

This theory was advanced by Gummesson (2002) and pointed that there exist relationships among human beings. Consequently, consumers define the brand relationship from their own individual perspectives and the brand relationship and relational value are very much personalized in the minds of consumers. Customers generate individual relationships based on their individual perception of brand value, brand meaning and their experiences. That is, customers seem to personally create the brand through their communications across multiple contexts (LindbergRepo, 2009). Prior research has also explored the personal component of the relationship between a brand and its customers. Fournier (2008) examined the nature of relationships that customers have as well as want to have with companies.

\section{METHODOLOGY}

The research was descriptive. For the purpose of the study, this approach was considered suitable as a method of eliciting information needed in drawing useful conclusions from the research study. The study was purely quantitative in nature. Population of the study was past and current students of the university. Five hundred and seventy five (575) persons were sampled using Convenience sampling method out of the population. Multiple linear regression was used to analyze data. 


\section{ANALYSIS OF DATA}

Cronbach's alpha analysis was used to determine the reliability of the Corporate Identity and Corporate Image scale used. Using a sample of 575 persons, Table 1 below presents a summary of the reliability statistics of the three major scales used in the study.

Table 1: Reliability Statistics (Cronbach's Alpha) for Scales used

\begin{tabular}{|c|c|c|}
\hline Scale & $\boldsymbol{\alpha}$ & No. of items \\
\hline Corporate Identity & .70 & 6 \\
\hline Corporate Image & .72 & 8 \\
\hline Marketing Performance & .68 & 4 \\
\hline
\end{tabular}

Source: Field Survey, 2019

From the Table above, it can be observed that, the reliability coefficients for the Corporate Identity, Corporate Image and Performance as used in the survey are .70, .72 and .68 respectively. According to Wells and Wollack (2003), a Cronbach alpha of .70 and beyond can be considered reliable whiles that between .65 and .70 can be termed as minimally acceptable. This means that, they are high or good in reliability and for that matter can be used for hypothesis testing (Wells and Wollack, 2003).

\section{Balance between CSUC Corporate Identity and Corporate Image}

Table 2 below presents the data from assessing the balance between CSUC corporate identity and corporate image. The Christian values identity of CSUC fit what respondents (students) expected before admission had a mean and standard deviation of 3.44 and 1.24 respectively whiles What CSUC communicate (promotes) outside is what the institution is doing inside had a mean of 3.14 and a standard deviation of 1.31. Furthermore, CSUC graduates' performance at various organizations fit what you think CSUC wants to achieve had a mean of 3.01 and a standard deviation of 1.51 whiles CSUC day to day activities is in line with realizing the university's vision had a mean of 2.96 and a standard deviation of 1.43. Lastly, students' perception about lecturers of CSUC is what the institution is promoting and CSUC outside image is what you think is happening on campus had means and standard deviation of $(\mathrm{M}=2.36 ; \mathrm{SD}=1.09)$ and $(\mathrm{M}=2.21 ; \mathrm{SD}=1.32)$ respectively.

Table 2: Balance between CSUC Corporate Identity and Corporate Image

\begin{tabular}{|c|c|c|}
\hline Response & Mean & SD \\
\hline The Christian values (identity) of CSUC fit what you expected before admission. & 3.44 & 1.24 \\
\hline $\begin{array}{c}\text { What CSUC communicates (promotes) outside is what the institution is doing } \\
\text { inside. }\end{array}$ & 3.14 & 1.31 \\
\hline $\begin{array}{l}\text { CSUC graduates' performance at various organizations fit what you think CSUC } \\
\text { wants to achieve. }\end{array}$ & 3.01 & 1.54 \\
\hline CSUC day to day activities is in line with realising the university's vision. & 2.96 & 1.43 \\
\hline $\begin{array}{l}\text { Your perception about lecturers of CSUC is what the institution says their } \\
\text { lecturers are. }\end{array}$ & 2.36 & 1.09 \\
\hline CSUC outside image is what you think is happening on campus. & 2.21 & 1.32 \\
\hline
\end{tabular}


Baofo, N. D., Agyapong, F., Asare, P., \& Amponsah, G. (2020) The Balance Between Corporate Identity And Corporate Image And Its Impact On Marketing Of Universities In Ghana. Archives of Business Research, 8(5). 302-315.

\section{Correlation Analysis}

A correlation analysis was conducted to observe the balance of corporate identity and image and its effect on marketing performance. From Table 3 below, it is observed that, a significant positive correlation exists between corporate identity, corporate image and its effect on marketing performance. This is to say that, the more effective the corporate identity of an organization is, the more the organizations' marketing performance increases.

Table 3: Correlation Results

\begin{tabular}{|c|c|c|c|c|c|c|}
\hline Variable & $\mathbf{N}$ & Mean & $\mathbf{1 .}$ & $\mathbf{2 .}$ & $\mathbf{3 .}$ & $\mathbf{4 .}$ \\
\hline $\begin{array}{c}\text { Corporate Identity and } \\
\text { image }\end{array}$ & 86 & 66.37 & $.11(.15)$ & & & \\
\hline Marketing Performance & 86 & 56.12 & $.26(.17) *$ & $.04(.22) *$ & - & \\
\hline
\end{tabular}

Correlation is significant at the 0.05 level (2-tailed).

\section{Regression Analysis On The Impact Of Corporate Identity And Marketing Performance}

The regression analysis provides information on the relationship that exists between corporate identity and performance.

Table 4 presents the model summary of the variables involved in this study. The R value of 1.227 shows the regression coefficient of corporate identity and organizational performance. The regression coefficient shows a high relation between corporate identity and marketing performance. The $\mathrm{R}^{2}$ value of 0.519 showed the coefficient of determination between corporate identity as well as marketing performance. The coefficient of determination showed that a $51.9 \%$ increase in marketing performance is caused by corporate identity.

Table 4: Model Summary

\begin{tabular}{|c|c|c|c|c|}
\hline Model & R & R Square & Adjusted R Square & Std. Error of the Estimate \\
\hline & $1.227^{\mathrm{a}}$ & .519 & .923 & 8.6529 \\
\hline \multicolumn{5}{|c|}{ a. Predictors: (Constant), corporate identity, performance } \\
\hline
\end{tabular}

Table 5 represents the effect (B), relationship (Beta) and significance (Sig.) of corporate identity on performance. The $\mathrm{B}$ value of 1.128 showed that corporate identity has a positive effect on performance. This means that an increase in corporate identity will influence marketing performance positively. The beta value of 0.974 showed that there is a strong positive correlation between corporate identity and marketing performance. The significant value of 0.05 showed that corporate identity is significant to performance.

Table 5: Coefficients

\begin{tabular}{|c|c|c|c|c|c|}
\hline \multirow[t]{2}{*}{ Model } & \multicolumn{2}{|c|}{$\begin{array}{l}\text { Unstandardized } \\
\text { Coefficients }\end{array}$} & \multirow{2}{*}{$\begin{array}{c}\begin{array}{c}\text { Standardized } \\
\text { Coefficients }\end{array} \\
\text { Beta }\end{array}$} & \multirow[t]{2}{*}{$\mathbf{t}$} & \multirow[t]{2}{*}{ Sig. } \\
\hline & B & Std. Error & & & \\
\hline (Constant) & 9.354 & 5.415 & & 4.148 & .011 \\
\hline Corporate Identity & 1.128 & 1.308 & .974 & 6.454 & .110 \\
\hline
\end{tabular}

a. Dependent Variable: Marketing Performance $\quad$ Sig. $<0.05$ 


\section{DISCUSSIONS}

Based on the above analysis, there is a fit between CSUC corporate identity and corporate image which has positively impacted on the university's marketing performance. This is based on the evidence that, majority of the responses attested to the fact that the university practised its Christian values inbuilt in its name, also the university does what it says it stands for from the various communication channels used in promoting the schools' image( that is Radio, Website, Tv, Personal selling teams and all Social media platforms). Test on practical performance of CSUC graduates on the field also fitted what the university promotes. This indicates that education attained at CSUC impacts positively on the performance of graduates as publicized by the university. Responses also indicated that majority of the students were satisfied with lecturers' performance at the time of the study. This was attested in the statement that lecturers' performance is what the university promotes in their communications to the public, which had a positive result.

A correlation analysis was conducted to observe the balance of corporate identity and image and its effect on marketing performance. It came out that, a significant positive correlation exists between corporate identity, corporate image and its effect on marketing performance. This is to say that, the more effective the corporate identity of an organization is, the more the organizations' performance increases.

The regression coefficient shows a high relationship between corporate identity and marketing performance. The $\mathrm{R}^{2}$ value of 0.519 showed the coefficient of determination between corporate identity as well as marketing performance. The coefficient of determination showed that a $51.9 \%$ increase in marketing performance is caused by corporate identity. The B value of 1.128 showed that corporate identity has a positive effect on performance. This means that an increase in corporate identity will influence marketing performance positively. The beta value of 0.974 showed that there is a strong positive correlation between corporate identity and marketing performance. The significant value of 0.05 showed that corporate identity is significant to performance.

\section{RECOMMENDATIONS AND CONCLUSIONS}

Customers generate individual relationships based on their individual perception of brand value, brand meaning and their experiences. That is, customers seem to personally create the brand through their communications across multiple contexts (Lindberg-Repo, 2009).With this understanding, and we can say that the corporate identity and image plays a critical role on marketing performance. This means that marketing success is largely based on the total performance of internal structures within a firm. While some people might believe that students are the sole customers of the educational service, others believe it is not only students but also parents, prospective employers, and society as a whole, as they all benefit from the service (Ivy \& Naude, 2004). On the basis of empirical findings, the researcher made these recommendations:

- Universities must create a perfect fit between their corporate identity and corporate image since these identities impact on their marketing performance.

- Also, the University identity must be seen to incorporate all the activities involved in the running of the institution, from advertising for students to performance of students on the field. 
Baofo, N. D., Agyapong, F., Asare, P., \& Amponsah, G. (2020) The Balance Between Corporate Identity And Corporate Image And Its Impact On Marketing Of Universities In Ghana. Archives of Business Research, 8(5). 302-315.

- Lastly, staff must be made to understand the relationship between the institution's corporate identity and corporate image and its impact on marketing performance of the institution.

\section{References}

Aaker, J. L. (2007) “Dimensions of Brand Personality”, Journal of Market Research, Vol. 34, No. 3, pp. 347-356.

Andersen, P. H. (2001) "Relationship development and marketing communication: an integrative model”, Journal of Business \& Industrial marketing, Vol. 16, No. 3, pp. 167-182.

Balmer J. M. T. (2003). Corporate brands: what are they? What of them?, European Journal of Marketing, Volume 37 Issue 7, pp. 972-997

Balmer J. M. T. (2007). Corporate identity: the concept, its measurement and management. European Journal of Marketing Volume 31 Issue 5, pp. 340-355. http://www.metro-as.no/Artikler/44Corporateidentity.pdf.

Banerjee, S. (2008) "Strategic Brand-Culture Fit: A conceptual framework for brand management", Journal of Brand Management, Vol. 15, No. 5, pp. 312-321.

Blackston, M. (2002), "A brand with an attitude: a suitable case for the treatment", Journal of the Market Research Society, Vol. 34 No. 3, pp. 231- 41.

Bronnenberg, B. J., and Wathieu, L. (1996) “Asymmetric Promotion Effects and Brand Positioning”, Marketing Science, Vol. 15, No. 4, pp. 379-394.

Carroll, C. E. (2013). The Future of Communication Research in Corporate Reputation Studies

Caruana, A.; and Chircop, S., (2000), “Measuring corporate reputation: A case example”, Corporate Reputation Review, Vol. 3, No. 1, pp.43-57.

Collins, J. C., and Porras, J. I. (2006) Build to last- Successful Habits of Visionary Companies, Harper Business Essentials, London.

De Chernatony, L. (2009) "Brand management through narrowing the gap between brand identity and brand reputation", Journal of Marketing Management, Vol. 15, No. 1-3, pp. 157-179.

De Chernatony, L., and Harris, F. (2001) "Corporate branding and corporate brand performance", European Journal of Marketing, Vol. 35, No. 3/4, pp. 441-456.

Dick, A. S., \& Basu, K. (2004). Customer loyalty: Towards an integrated conceptual framework. Journal of the Academy of Marketing Science, 22(2), 99-113.

Dobni, D., and Zinkhan, G. (2000) "In Search of Brand Image: A Foundation Analysis", Advances in Consumer Research, Vol. 17, No. 1, pp. 110-119.

European Institute for Brand Management. Birgit \& Stadler's Identity / Corporate Image Model. 2009. http://www.eurib.org/fileadmin/user_upload/Documenten/PDF/Reputatiemanagement ENGELS/v_Corporate_Identity_Corporate_Image_van_Birkigt_Stadler__EN_.pdf. Accessed 6 October 2018.

Fournier, S. (2008) "Consumers and Their Brands: Developing Relationship Theory in Consumer Research", Journal of Consumer Research, Vol. 24, No. 4, pp. 343-353.

Hsieh, M. H., Pan, S. L., \& Setiono, R. (2006). Product-, corporate-, and countryimage dimensions and purchase behavior: A multicountry analysis. Journal of the Academy of Marketing Science, 32(3), 251-270.

Janonis, V., Dovaliené, A., and Virvilaité, R. (2007) “Relationship of Brand Identity and Image”, Engineering Economics, Vol. 1, No. 51, pp. 69-79.

Kapferer, J.N. (2008) The new strategic brand management; Creating and sustaining brand equity long term, Fourth edition, Kogan page Limited, London and Philadelphia.

Keller, K.L., Sternthal, B., and Tybout, A. (2002) "Three questions you need to ask about your brand", Harvard Business Review, Vol. 80, No. 9, pp. 80-86. 
Keller, K.L. (2003), “Conceptualizing, measuring and managing customer-based brand equity”, Journal of Marketing, Vol. 57, January, pp. 1-22.

Koo, D. M (2003). Inter-relationships among store images, store satisfaction, and store loyalty among Korea discount retail patrons. Asia Pacific Journal of Marketing and Logistics, 15(4), 42-71.

Kotler, P. (2001). A framework for marketing management. Upper Saddle River, NJ: Prentice-Hall.

Kotler, P., and Gertner, D. (2002) "Country as brand, products, and beyond: A place marketing and brand management perspective”, Journal of Brand Management, Vol. 9, No. 4/5, pp. 249-262.

Lannon, J., and Cooper, P. (2003) "Humanistic advertising - a holistic cultural perspective", International Journal of Advertising, Vol. 2, No. 3, pp.195-213.

Lippincott (2015), Insights, Managing Image in a Dynamic Corporate Environment.

http://www.lippincott.com/en/insights/managing-image-in-a-dynamiccorporate- environment.

Management Study Guide 2015, Library, Marketing, Brand Management, Brand Identity vs Brand Image. http://www.managementstudyguide.com/identity-vsimage. htm. Accessed 6 October 2018.

Meenaghan, T. (2005) "The role of advertising in brand image development”, Journal of Product \& Brand Management, Vol. 4, No. 4, pp. 23-35.

Munoz, T. (2004) "Brand metrics: Gauging and linking brands with business performance", Journal of brand management, Vol.11, No. 5, pp. 381-387.

Otubanjo, O. (2013). The Extended Corporate Identity Mix. International Journal of Marketing Studies Vol. 5, No. 1, pp. 59-60. http://www.ccsenet.org/journal/index.php/ijms/article/viewFile/23932/15169.

Pitkänen, K. P. (2001) Yrityskuva ja maine menestystekijöinä, pp. 15-16

Ponnam, A. (2007) "Comprehending the Strategic Brand Building Framework of Kingfisher in the Context of Brand Identity Prism”, Journal of Brand Management, Vol. 4, No. 4, pp. 63-71.

Pownall, C. (2011). Managing Corporate Reputation in the Digital Age.

http://www.wpp.com/ /media/SharedWPP/ReadingRoom/Digital/managing_corporate_reputation.pdf.

Real Staffing (2015), Employers, Recruitment guides, Building a compelling employer brand. http://www.realstaffing.com/employers/recruitmentguides/ building-a-compelling-employer-brand.

Sääksjärvi, M., and Samiee, S. (2011) "Relationships among brand identity, brand image and brand preference: differences between cyber and extension retail brands over time”, Journal of interactive marketing, Vol. 25. No. 3, pp. 169-177.

Schein, E.H. (2004) “Coming to a New Awareness of Organizational Culture”, Sloan Management Review, Vol. 25, No. 2, pp. 3-16.

Sujan, M., and Bettman, J.R. (2009) “The Effects of Brand Positioning Strategies on Consumers' Brand and Category Perceptions: Some Insights from Schema Research”, Journal of Marketing Research, Vol. 26, No. 4, pp. $454-467$.

Swaminathan, V., Stilley, K., and Ahluwalia, R. (2009) "When Brand Personality Matters: The Moderating Role of Attachment Styles", Journal of Consumer Research, Vol. 35, No. 6, pp. 985-1002.

Villanova, L., Zinkhan, G.M. and Hyman, M.R. (2000) 'On Defining and Measuring Store Image’, in B.J. Dunlap (ed.) Proceedings of the Thirteenth Annual Conference of the Academy of Marketing Science, April, pp. 466-70. New Orleans, LA: Academy of Marketing Science.

Weiwei, T. (2007). Impact of Corporate Image and Corporate Reputation on Customer Loyalty: A Review. Management Science and Engineering Vol.1

Williams, M., Buttle, F., and Biggemann, S. (2012). Relating Word-of-Mouth to Corporate Reputation. Public Communication Review Vol. 2 No. 2a 